\title{
IMPLEMENTASI KEGIATAN PEMBELAJARAN DARING DI MASA PANDEMI COVID-19 UNTUK MENSTIMULASI KEMAMPUAN PRA-CALISTUNG ANAK USIA 3 - 4 TAHUN DI DIKARA EDU CENTER KEDAMEAN - GRESIK
}

\author{
Umi Masturoh ${ }^{1, a)}$, Fitrianti Wulandari ${ }^{2)}$ \\ ${ }^{1,2)}$ Program Studi Pendidikan Islam Anak Usia Dini \\ Sekolah Tinggi Agama Islam Al Azhar Menganti Gresik

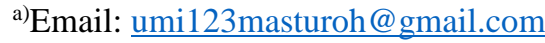

\begin{abstract}
Abstrak
Tujuan dari penelitian ini adalah untuk mengetahui implementasi kegiatan pembelajaran daring di masa pandemi covid-19 untuk menstimulasi kemampuan Pra-calistung (membaca, menulis dan berhitung) anak usia 3 - 4 tahun di Dikara Edu Center (DEC) Miru Banyuurip Kedamean Gresik. Jenis penelitian ini masuk dalam kategori penelitian lapangan (field research) sedangkan metode yang digunakannya adalah deskriptif. Adapun hasil dari penelitian ini adalah implementasi kegiatan pembelajaran daring dalam menstimulasi kemampuan pra-calistung anak usia 3 - 4 tahun yang ada di Desa Banyuurip Kedamean Gresik, pada penerapan daring adalah dengan memanfaatkan aplikasi whatsapp, video call dan memanfaatkan worksheet yang relevan dengan materi yang akan disampaikan, stimulasi kemampuan pra-calistung anak usia 3 - 4 tahun di Dikara Edu Center (DEC) Miru Banyuurip Kedamean Gresik terhadap kemampuan pra membaca, menulis dan menghitungnya terbilang masih sangat rendah, baik dilihat dari sikap pada saat proses pembelajaran maupun hasil dalam pembelajaran yang disebabkan kurang efektifnyanya pendampingan dari guru secara langsung karena kondisi pandemi Covid-19. Simpulan hasil dari penelitian ini diketahui bahwa implementasi kegiatan pembelajaran daring di masa pandemi covid-19 untuk menstimulasi kemampuan Pra-calistung (membaca, menulis dan berhitung) anak usia 3 - 4 tahun di Dikara Edu Center (DEC) Miru Banyuurip Kedamean Gresik terhadap kemampuan pra calistung terbilang masih sangat rendah dibanding pada masa normal.
\end{abstract}

Kata kunci: Pembelajaran Daring, Menstimulasi Pra-Calistung, Anak Usia Dini

\begin{abstract}
The purpose of this study was to determine the implementation of online learning activities during the COVID-19 pandemic to stimulate the Pre-calistung (reading, writing, and arithmetic) abilities of children aged 3 - 4 years at the Dikara Edu Center (DEC) Miru Banyuurip Kedamean Gresik. This type of research is included in the field research category, while the method used is descriptive. The results of this study are the implementation of online learning activities in stimulating the pre-calistung abilities of children aged 3-4 years in the village of Banyuurip Kedamean Gresik, on the online application is to use the WhatsApp application, video calls and use worksheets that are relevant to the material to be studied. As conveyed, the stimulation of pre-calistung abilities of children aged 3-4 years at the Miru Edu Center (DEC) Miru Banyuurip Kedamean Gresik on pre-reading, writing, and counting abilities is still very low, both seen from the attitude during the learning process and the results in the learning process. This is due to the ineffectiveness of mentoring from direct teachers due to the Covid-19 pandemic. The conclusion from this research is that the implementation of online learning activities during the covid-19 pandemic is to stimulate the Pre-calistung (reading, writing, and arithmetic) abilities of children aged 3 - 4 years at Dikara Edu Center (DEC) Miru Banyuurip Kedamean Gresik towards pre-school skills. Calistung is still very low compared to normal times.
\end{abstract}

Keywords: Online Learning, Stimulating Pre-Calistung, Early Childhood

\section{PENDAHULUAN}

Pendidikan bagi anak usia dini sangat penting dilakukan karena dalam pendidikan tersebut merupakan dasar bagi pembentukan kepribadian anak dan sebagai peletak dasar budi pekerti luhur, kepandaian dan keterampilan. Menurut

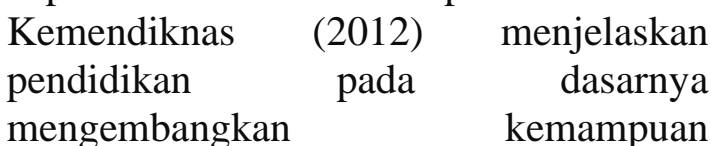


pembelajaran, pembiasaan dan keteladanan agar anak menjadi cerdas dan berkarakter mulia.

Suasana belajar yang diperlukan anak usia dini adalah suasana belajar yang nyaman, tidak membebani anak dan mengarah pada pembelajaran perpusat anak (child centered) serta memperoleh banyak pengetahuan yang lebih banyak dari pengalaman langsung. Anak sebagai individu yang aktif maka pengetahuan lebih banyak diperoleh dari pengalaman dalam melakukan berbagai aktivitas. Sedangkan kenyataannya kegiatan belajar mengajar yang berlangsung secara rutin tanpa memberikan pengalaman dan peluang anak untuk mengikuti atau mencoba dapat menimbulkan kebosanan pada kegiatan belajar dan mengakibatkan anak akan kesulitan memperoleh pengetahuan. Piaget (Sujiono, 2009) menjelaskan bahwasanya cara belajar anak adalah active learning dimana pembelajaran lebih banyak di dapat dengan cara pengalaman yang konkret atau langsung memberikan kesempatan kepada anak untuk melakukannya.

Indonesia merupakan salah satu negara yang terinfeksi pandemi Covid-19. Penyakit Corona virus 2019 (Covid-19) adalah penyakit menular yang disebabkan oleh sindrom pernapasan akut corona virus 2 (SARS-CoV-2). Covid-19 pertama dilaporkan di Indonesia pada tanggal 2 Maret 2020 sejumlah dua kasus. Data 31 Maret 2020 menunjukkan kasus yang terkonfirmasi berjumlah 1.528 kasus dan 136 kasus kematian. Penyakit Covid-19 ini pertama kali diidentifikasi pada Desember 2019 di Wuhan, ibu kota provinsi Hubei China, dan sejak itu menyebar secara global, mengakibatkan pandemic corona virus 2019 hingga sedang berlangsung sekarang 2021.

Manusia merupakan mahluk sosial yang tidak bisa hidup sendiri pasti memerlukan hubungan dengan manusia lain, hal itu memungkinkan dengan adanya saling berinteraksi secara langsung sehingga tingkat penyebaran pandemi Covid-19 semakin pesat. Sehingga Pemerintah tengah menyiapkan aturan karantina kewilayahan atau lockdown untuk memutuskan matarantai penyebaran virus corona atau COVID 19.

Dengan adanya pandemik Covid-19 berdasarkan surat edaran dari Menteri Pendidikan dan Kebudayaan (Mendikbud) Nadiem Anwar Makarim menerbitkan Surat Edaran Nomor 4 Tahun 2020 menetapkan Pelaksanaan Pendidikan Dalam Masa Darurat Corona Virus Disease (Covid-19) atau bahasa sederhananya sistem pembelajaran dilaksanakan dirumah atau disebut daring. Dengan adanya pembatasan interaksi, Kementerian Pendidikan di Indonesia juga mengeluarkan kebijakan yaitu dengan meliburkan sekolah dan mengganti proses Kegiatan Belajar Mengajar (KBM) dengan menggunakan sistem dalam jaringan (daring). Dengan menggunakan sistem pembelajaran secara daring ini, terkadang muncul berbagai masalah yang dihadapi oleh anak dan guru, seperti materi pelajaran yang belum selesai disampaikan oleh guru kemudian guru mengganti dengan tugas lainnya. Hal tersebut menjadi keluhan bagi anak karena tugas yang diberikan oleh guru lebih banyak.

Kegiatan pembelajaran daring merupakan proses kegiatan belajar mengajar yang banyak memanfaatkan jaringan internet. Dengan pembelajaran daring yang dilakukan seorang guru dalam mendampingi dan memberikan instruksi kegiatan pada anak yang dilakkan dengan jarak jauh amat sangat memberikan keleluasaan waktu belajar, sehingga seorang guru bisa melakukan kapanpun sesuai dengan aturan standar operasional prosedur sekolah dalam memberikan kegiatan pembelajaran dan anak pun saat mengerjakan tugas yang diberikan guru bisa lebih fleksibel karena dapatbelajar kapanpun dan dimanapun. 
Kegiatan pembelajaran yang dilakukan secara daring, seorang anak di Dikara Edu Center (DEC) Miru Banyuurip Kedamean Gresik dapat berinteraksi dengan guru menggunakan beberapa aplikasi seperti classroom, video converence, telepon atau live chat, zoom, google meet, maupun melalui whatsapp group. Menurut Sahidillah dan Miftahurrizqi (Dwijo et al., 2020) menegaskan media WhatsApp memudahkan komunikasi terjalin karena bisa interaksi dengan diskusi melalui chating pesan dan mengirimkan materi pembelajaran tidak menghasilkan biaya mahal karena pemakaian menggunakan data internet bukan pulsa serta sebagian besar orang tua dapat menggunakan aplikasi tersebut.

Berbagai macam aplikasi yang saat ini sedang beredar di media sosial tersebut amat sangat mendukung untuk menyampaikan segela bentuk pembelajaran atau informasi yang disampaikan seorang guru kepada anak atau juga kepada orangtua. Dalam hal ini, orangtua juga berperan sangat penting pada pelaksanaan kegiatan yang dilakukan anak dan gurunya secara daring. Albrecht dan Miller (Sujiono, 2013) menambahkan bahwa pembelajaran bagi anak usia dini seharusnya sarat dengan aktivitas yang mengutamakan adanya kebebasan untuk bereksplorasi dan berkreativitas, sedangkan orang dewasa seharusnya lebih berperan sebagai fasilitator saat anak membutuhkan bantuan untuk memecahkan masalah yang dihadapi seorang anak.

Kegiatan membaca, menulis dan berhitung atau yang lebih populer dikenal dengan singkatan kata Calistung adalah suatu metode pengenalan yang amat dasar pada anak. Kegiatan calistung ini biasanya berisikan kegiatan yang menitikberatkan pada kegiatan pra pengenalan simbolsimbol huruf dan angka. Kemampuan anak pada saat kegiatan berhitung merupakan kemampuan yang banyak menggunakan aspek perkembangan kognitif yang menjadi dasar pengembangan auditori, pengembangan visual, pengembangan taktil, pengembangan kinestetik, pengembangan aritmatika, pengembangan geometri, pengembangan sains permulaan (Depdiknas, 2007).

Keterampilan pembelajaran pracalistung atau kegiatan lainnya yang dapat mengembangkan seluruh aspek perkembangan yang ada pada anak usia dini bisa dikenalkan pada anak berusia 3 - 4 tahun, usia-usia ini adalah usia emas yang harus diberi stimulus secara maksimal. hal ini sejalan dengan hasil penelitian menunjukkan bahwa sekitar $50 \%$ variabilitas kecerdasan orang dewasa sudah terjadi ketika anak berusia 4 tahun. Peningkatan $30 \%$ berikutnya terjadi pada usia 8 tahun, dan $20 \%$ sisanya pada pertengahan atau akhir dasawarsa kedua (Samani, 2011). Hal ini dapat diambil kesimpulan bahwasannya kegiatan membaca, menulis, dan berhitung merupakan salah satu aktivitas yang paling penting dalam hidup dan dapat dikatakan bahwa semua proses belajar didasarkan pada kemampuan membaca, yaitu memahami.

Calistung adalah tahapan dasar orang bisa mengenal simbol huruf dan angka. Dengan kegiatan pra-membaca yang dilakukan seorang anak diharapkan anak kedepannya mampu dan mudah menyerap berbagai macam informasi, dengan kegiatan pra-menulis mampu melatih kemampuan motorik halus di sekitar otototot jari tangan seorang anak, sedangkan dengan kegiatan pembelajaran pramenghitung akan meningkatkan kemampuan otak dalam mengolah dan memecahkan informasi dasar yang sangat sedehana untuk anak. Adapun tujuan dari penelitian ini adalah untuk mengetahui sejauh mana penerapan atau implementasi pada kegiatan pembelajaran daring di masa pandemi covid-19 untuk menstimulasi kemampuan Pra-calistung (membaca, 
menulis dan berhitung) anak usia 3-4 tahun di Dikara Edu Center (DEC) Miru Banyuurip Kedamean Gresik.

\section{METODE PENELITIAN}

Penelitian implementasi pada kegiatan pembelajaran daring di masa pandemi covid-19 untuk menstimulasi kemampuan Pra-calistung (membaca, menulis dan berhitung) anak usia $3-4$ tahun di Dikara Edu Center (DEC) Miru Banyuurip Kedamean Gresik ini adalah penelitian lapangan (field research) dimana seorang peneliti terlibat langsung untuk ikut serta ke lokasi yang dijadikan sebagai tempat penelitian, agar hasil perolehan data yang dibutuhkan bisa dikatakan sangat relevan dengan indikator dalam tujuan penelitian. Jenis pendekatan pada penelitian ini adalah metode deskriptif, dan penelitian ini merupakan penelitian kualitatif yang bersumber dari kata-kata tertulis, atau hasil wawancara dari orangorang dan perilaku yang dapat diamati langsung dari peneliti. Penelitian ini dilakukan pada satuan kegiatan sosial Dikara Edu Center yang ada di Dusun Miru Desa Banyuurip kecamatan Kedamean kota Gresik. Durasi waktu penelitian yang dibutuhkan selama 11 minggu yang dimulai pada tanggal 1 Maret 2021 sd 15 Mei 2021.

\section{HASIL DAN PEMBAHASAN}

Pembelajaran jarak jauh atau yang dikenal dengan istilah pembelajaran daring merupakan pembelajaran yang dilakukan tanpa tatap muka secara langsung antara guru dengan anak. Pembelajaran daring atau pembelajaran jarak jauh ini dirasa sangat efektif untuk saat ini, guna memutus mata rantai penyebaran virus covid-19. Selama masa pandemi kegiatan pembelajaran yang diterapkan oleh guru yang kedapatan mendapat mengajar di kelompok bermain anak usia usia 3 - 4 tahun di Dikara Edu Center (DEC) Miru Banyuurip Kedamean Gresik belum berjalan cukup efektif.
Jika di masa normal kegiatan dilakukan secara tatap muka dan semua aktivitasnya dilakukam secara praktek langsung. Karena kondisi saat ini tidak memungkinkan untuk melakukan pembelajaran secara langsung dan berdasarkan surat edaran dari Menteri Pendidikan dan Kebudayaan (Mendikbud) Nadiem Anwar Makarim menerbitkan Surat Edaran Nomor 4 Tahun 2020 menetapkan Pelaksanaan Pendidikan Dalam Masa Darurat Coronavirus Disease (Covid-19), untuk itu guru di Dikara Edu Center (DEC) hanya memanfaatkan video pembelajaran, namun untuk pemberian kegiatan yang sifatnya tertulis dan praktik seperti yang dipaparkan oleh guru kelompok sebagai model pembelajaran daring yang digunakan yaitu video pembelajaran yang berisikan tentang penugasan tertulis dan praktik.

Hal ini disebabkan dikarenakan karakteristik dari masing-masing anak berbeda, ada anak yang daya memahaminya sangat cepat namun ada juga yang rendah. Untuk itu, guru yang ada di Dikara Edu Center (DEC) berusaha memberikan kegiatan pembelajaran dari secara exstra yang dikhususkan untuk mendampingi anak-anak yang masih butuh pendampingan langsung dalam hal pembelajaran pra-calistung (membaca, menulis dan berhitung). Pelaksanaan kegiatan pembelajaran pada anak usia dini adalah suatu proses yang diatur sedemikian rupa menurut langkahlangkah yang disusun dan terencana dalam rencana pelaksanaan pembelajaran harian (RPPH) agar pelaksanaan mencapai hasil yang diharapkan.

Rencana pelaksanaan pembelajaran harian (RPPH) yang dirancang oleh guru selama masa pandemi ini sama dengan pembuatan RPPH pada umumnya, namun dalam pembelajaran daring ini guru membuat RPPH yang lebih ringkas yaitu penggunaan RPPH daring satu lembar sesuai dengan anjuran yang diberikan oleh 
pemerintah sebagai rancangan darurat. Dalam proses pembelajaran daring ini guru memberikan video pembelajaran kepada anak setiap hari melalui aplikasi whatsapp dan melakukan review materi di setiap minggunya, seperti yang dipaparkan oleh guru di Dikara Edu Center (DEC).

Begitu juga dengan nilai yang didapatkan anak dari hasil kegiatan yang dilakukan selama pembelajaran daring, penilaian adalah bagian yang sangat penting di dalam dunia pendidikan, karena penilaian merupakan bahan yang digunakan oleh guru untuk mengevaluasi seorang anak selama proses pembelajaran. Evaluasi yang dilaksanakan dalam proses pembelajaran daring yaitu dengan pemberian tugas sederhana kepada anak dalam bentuk tertulis maupun dalam bentuk video, seperti yang telah diungkapkan dalam wawancara peneliti dengan guru kelompok anak usia $3-4$ tahun.

Evaluasi yang diberikan juga dapat berupa pengambilan tugas dan pengumpulan tugas secara langsung ke Dikara Edu Center (DEC) yang didampingi oleh orang tua anak dengan bantuan materi yang bersumber dari worksheet/lembar kerja yang telah diselesaikan anak. Evaluasi yang dilakukan oleh guru kelompok anak usia 3 - 4 tahun ini dirasa cukup efektif karena evaluasi tidak hanya dilakukan secara tatap muka melalui aplikasi whatsapp dan video call, atau penugasan melalui aplikasi whatsapp saja. Namun evaluasi juga dapat berbentuklembar kerja tertulis yang dapat diambil dan dikumpulkan langsung ke Dikara Edu Center (DEC).

Selama kegiatan pembelajaran yang dilakukan seorang guru dan anak semasa pandemi, banyak faktor yang ditemui baik itu faktor yang mendukung atau menghambat proses pembelajaran. Di dalam penelitian ini, peneliti memaparkan faktor penghambat dalam implementasi pembelajaran yang dilakukan secara daring terlebih dahulu, karena dalam prosespembelajaran ini anak tidak dapat bertatap muka langsung dengan guru, maka orang tualah yang menjadi guru utama saat anak melakukan kegiatan di rumah.

Orang tua yang terlibat dalam kegiatan pembelajaran daring yang dilakukan guru Dikara Edu Center (DEC) dan anak, amat banyak melibatkan keterlibatan orangtua baik dalam hal menyiapkan selama proses kegiatan berlangsung maupun pendampingan saat berkegiatan. Berbagai macam latar belakang pekerjaan orang tua anak membuat pembelajaran daring itu sendiri menjadi kurang maksimal, dikarenakan orang tua anak tidak dapat mendampingi anaknya dalam mengikuti pembelajaran daring secara kondisional sehingga berdampak pada kurangnya efektifitas dan efisiensi waktu dalam proses pembelajaran daring. Disisi lain seorang guru diharuskan untuk selalu siap mendampingi anak dari pagi hingga malam hari. Hal ini berkaitan dengan kinerja guru, dimana yang seharusnya guru mempersiapkan materi untuk hari berikutnya, seringnya tidak terlaksana dengan baik. Baik orangtua, anak maupun guru sepertinya cukup terbebani oleh materi yang belum tuntas dihari tersebut.

Faktor pendukung pembelajaran daring, dalam mengimplementasikan pembelajaran daring dengan anak, guru tentu harus melibatkan orang tua, dimana peran orang tua adalah kunci sukses dari proses pembelajaran daring itu sendiri. Dalam pembelajaran daring pun, diperlukan kuota internet yang memadai maupun kualitas sinyal yang stabil guna menunjang keberhasilan pembelajaran daring. Selain itu adapun faktor pendukung lainnya dalam pembelajaran daring yaitu, sekolah memfasilitasi jaringan wifi untuk guru sebagai sarana untuk memberikan materi pembelajaran daring selama guru masih berada di lingkungan sekolah. Namun jaringan wifi 
tersebut hanya bisadigunakan ketika guru masih di dalam lingkungan sekolahan, namun jika guru berada di rumah dan kegiatan pembelajaran daring masih berlangsung, hal tersebut akan membuat guru harus mengeluarkan biaya sendiri untuk membeli kuota internet di luar jam pembelajaran.

Berdasarkan hasil penjelasan di atas mengenai faktor pendukung dan penghambat atau lainnya maka peneliti mengambil kesimpulan bahwa implementasi kegiatan pembelajaran daring di masa pandemi covid-19 untuk menstimulasi kemampuan Pra-calistung (membaca, menulis dan berhitung) anak usia 3 - 4 tahun di Dikara Edu Center (DEC) Miru Banyuurip Kedamean Gresik, khususnya terhadap kemampuan membaca, menulis dan menghitung masih sangat rendah, baik dilihat dari sikap pada saat proses pembelajaran maupun hasil nilai dalam pembelajaran yang dilakukan secara daring. Berdasarkan pemaparan itu, maka perlu diupayakan inovasi kegiatan pembelajaran untuk mengoptimalkan peran anak dalam menyelesaikan seperangkat kegiatan sehingga berjalan dengan aktif dan produktif, tercipta suasana belajar penuh semangat, bahkan hasil belajar pun bermakna bagi anak.

Menurut Sujiono (2013), kegiatan pembelajaran pada anak usia dini pada hakikatnya adalah pembelajaran secara konkret berupa sejumlah pengalaman belajar melalui bermain yang diberikan pada anak usia dini berdasarkan potensi dan tugas perkembangan yang harus dikuasainya. Jadi, unsur utama dalam pengembangan program pembelajaran bagi anak usia dini adalah kegiatan belajar dengan bermain. Selain itu untuk meningkatkan kemampuan anak dalam kegiatan pra-calistung pada masa Pandemi Covid 19.

Berdasarkan dari apa yang dipelajari seorang anak selama berkegiatan secara daring, anak cukup belajar menghubungkan antara konsep-konsep baru dengan konsep-konsep lama yang mereka miliki. Pada masa pandemi seperti ini anak belajar untuk membentuk konsepkonsep tentang angka, waktu, ruang, fungsibadan, peran jenis kelamin, moral. Pembelajaran pada anak usia dini cepat dipahami anak, apabila anak dilibatkan langsung melakukan atau praktik apa yang diajarkan gurunya. Berdasarkan teori tersebut maka jelas bahwa kehadiran guru ditengah-tengah anak dalam pembelajaran pra-calistung atau lainnya sangat diperlukannya kehadiran guru dalam mendampingi anak dalam belajar, sehingga pembelajaran dapat berjalan efektif untuk anak kelompok usia 3-4 tahun.

Berdasarkan hasil observasi dan wawancara yang dilakukan seorang peneliti dengan salah satu guru pada kemampuan pra-membaca anak usia 3 4 tahun di Dikara Edu Center (DEC) Miru Banyuurip Kedamean Gresik, dasar membaca hampir keseluruhan anak sudah mampu membaca namun masi ada beberapa anak memang belum lancar dalam membaca, namun untuk aspek pengenalan huruf dalam mengenal suku kata dasar hampir keseluruhan anak belum mampu dan hal ini juga pada aspek memahami ragam simbol bacaan huruf yang dibacaan anak usia 3-4 tahun masih belum mampu, hal ini terindikasi bahwa kegiatan pembelajaran daring belum bisa menstimulasi dalam kemampuan memahami simbol huruf dan memahami ragam suku kata dasar, untuk indikator membaca anak implementasi kegiatan pembelajaran daring tidak dapat meningkatkan kemampuan memabaca sebagaimana indikator dalam penelitian kemampuan membaca yang harus meliputi kemampuan memahami beragam simbol huruf.

Berikutnya dibahas juga tentang kemampuan pra-menulis anak usia $3-4$ tahun untuk mengenal huruf sudah bagus, namun masih rendahnya kemampuan anak dalam menarik garis atau menyamakan 
simbol masih banyak anak yang belum mampu menuntaskan tugas yang diberikan sesuai instruksi sederhana oleh guru pada saat peneliti melakukan observasi dan wawancaranya, namun dalam hal mendeskripsikan dan menuliskan benda disekitar anak melalui kegiatan menebali titik-titik sudah cukup bagus. Dari hal tersebut, maka disimpulkan bahwa implementasi pembelajaran daring belum dapat mememenuhi aspek pra-menulis sebagaimana indikator yang telah ditetapkan dalam penelitian, hal ini sebagaimana menurut Nurcholis dan Mafrukhi (1996) bahwasannya rendahnya kemampuan membaca, menulis dan menghitung anak tidak adanya alat bantu anak untuk mengeluarkan ide pemikirannya juga ketidakhadiran guru langsung dalam mendampingi anak selama pembalajaran.

Proses pembelajaran secara daring di di Dikara Edu Center (DEC) Miru Banyuurip Kedamean Gresik yaitu guru memberikan bimbingan kepada anak hanya dengan penugasan melalui worksheet dan kelas online saja tanpa ada pendampingan khusus bagi anak yang mengalami kesulitan belajar. Anak pada kategori rendah merupakan anak yang membutuhkan dukungan guru secara langsung dalam memberikan pembelajaran, dalam menstumulasi kemampuan membaca, menulis dan berhitung atau Calistung.

Berdasarkan dari penjelasan yang telah disampaikan di atas, juga diperkuat berdasarkan prinsip umum tentang mengajar menurut Uno (2011) bahwasannya (1) mengajar harus berdasarkan pengalaman yang sudah dimiliki masin-masing anak. Apa yang telah dipelajari merupakan dasar dalam mempelajari bahan yang akan diterimanya. Oleh karena itu, tingkat kemampuan seorang anak sebelum proses belajar mengajar berlangsung harus diketahui oleh seorang guru terlebih
dahulu.Hal ini sangat penting agar proses belajar dapat berlangsung secara efektif dan efisien, dan (2) pada saat mengajar seorang guru harus memperhatikan perbedaan individual setiap anak. Ada banyak perbedaan individual dalam kesanggupan belajar. Setiap individu mempunyai kemampuan potensial seperti bakat dan inteligensi yang berbeda antara satu anak dengan yang lainnya. Apa yang dipelajari seseorang secara cepat, mungkin tidak dapat dilakukan oleh yang lain dengan cara yang sama. Untuk itu, seorang guru pada saat mengajar harus memperhatikan perbedaan tingkat kemampuan masing-masing anak. Sejalan dengan penjelasan Nasution dalam Maswan dan Khoirul Muslimin berpendapat bahwa mengajar adalah "suatu aktivitas mengorganisasi atau mengatur lingkungan sebaik-baiknya dan menghubungkannya dengan anak, sehingga terjadi proses belajar yang efektif namun menyenangkan dan membekas".

\section{KESIMPULAN}

Kesimpulan dari penelitian implementasi kegiatan pembelajaran daring di masa pandemi covid-19 untuk menstimulasi kemampuan Pra-calistung (membaca, menulis dan berhitung) anak usia 3 - 4 tahun di Dikara Edu Center (DEC) Miru Banyuurip Kedamean Gresik, kegiatan pembelajaran daring yang dilakukan dengan memanfaatkan aplikasi seperti classroom, video converence, telepon atau live chat, zoom, google meet, maupun melalui whatsapp group dan memanfaatkan sumber belajar worksheet yang relevan dengan materi yang akan disampaikan masih kurang baik hasilnya dibanding kegiatan belajar yang dilakukan dengan tatap muka secara langsung. Implementasi kegiatan pembelajaran daring dalam menstimulasi kemampuan Pra-calistung (membaca, menulis dan berhitung) anak usia 3 - 4 tahun di Dikara Edu Center (DEC) Miru Banyuurip 
Kedamean Gresik terhadap kemampuan membaca, menulis dan menghitungnya masih sangat rendah, baik dilihat dari sikap pada saat proses pembelajaran daring maupun hasil dalam pembelajaran yang disebabkan kurangnya pendampingan dari guru langsung karena kondisi pandemi Covid-19.

\section{UCAPAN TERIMA KASIH}

Terima kasih disampaikan kepada pihak-pihak yang telah membantu dalam proses penelitian ini sehingga dapat selesai dengan baik dan tepat waktu. Terima kasih disampaikan kepada para rekan sejawat, dosen, dan Prodi Pendidikan Islam Anak Usia Dini STAI Al-Azhar Menganti Gresik.

\section{DAFTAR PUSTAKA}

Departemen Pendidikan Nasional. (2007). Pedoman Pembelajaran Bidang Pengembangan Kognitif di Taman Kanak-kanak. Jakarta: Depdiknas.

Dwijo et al. (2020). Penerapan Metode Pembelajaran Melalui Media WhatsApp Selama Pandemi COVID19 di RA Al-Qodir. JECED: Journal of
Early Childhood Education and Development 2(2):124-31. doi: 10.15642/jeced.v2i2.840.

Kementerian Pendidikan Nasional. (2012). Pedoman Pendidikan Karakter pada Pendidikan Anak Usia Dini. Jakarta: Kemendiknas.

Nurcholis \& Mafrukhi. (1996). Saya Senang Berbaha Indonesia: sasebi. Jakarta : Erlangga.

Samani, Muchlas \& Hariyanto. (2011). Konsep dan Model Pendidikan Karakter. Bandung: PT Remaja Rosdakarya.

Sujiono, Yuliani Nurani. (2009). Konsep Dasar Pendidikan Anak Usia Dini. Jakarta: PT Indeks.

Sujiono, Yuliani Nurani. (2013). Bermain Kreatif Berbasis Kecerdasan Jamak. Jakarta: Indeks.

Uno, Hamzah B. (2011). Model Pembelajaran. Jakarta: Bumi Aksara. 